Orenes ans When id Necher 8

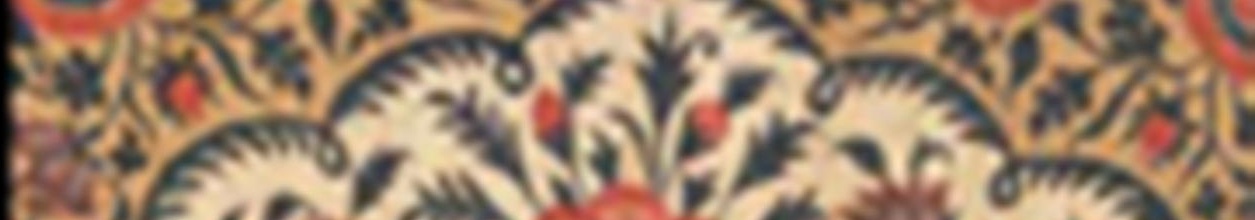

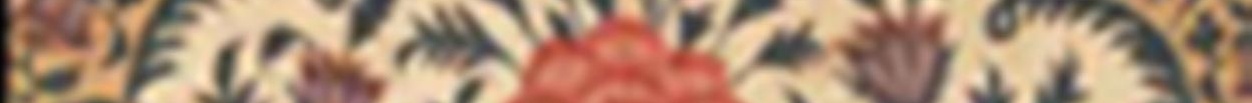

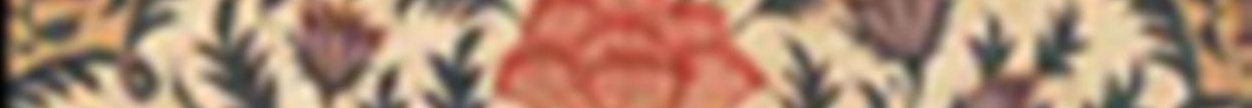

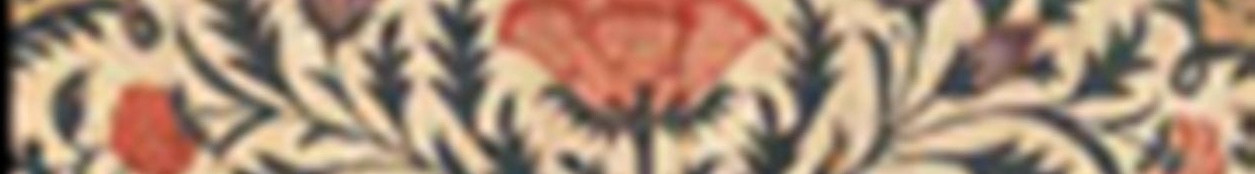

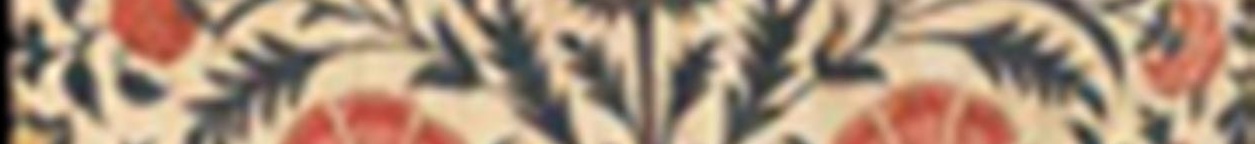

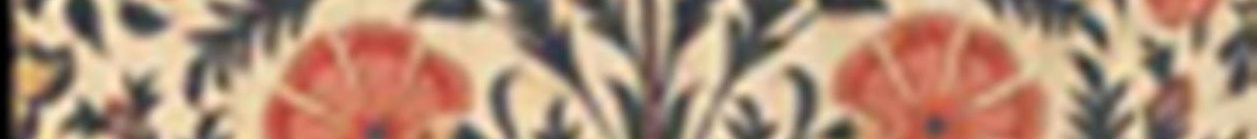

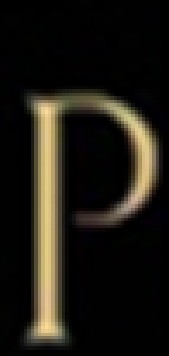

Suly

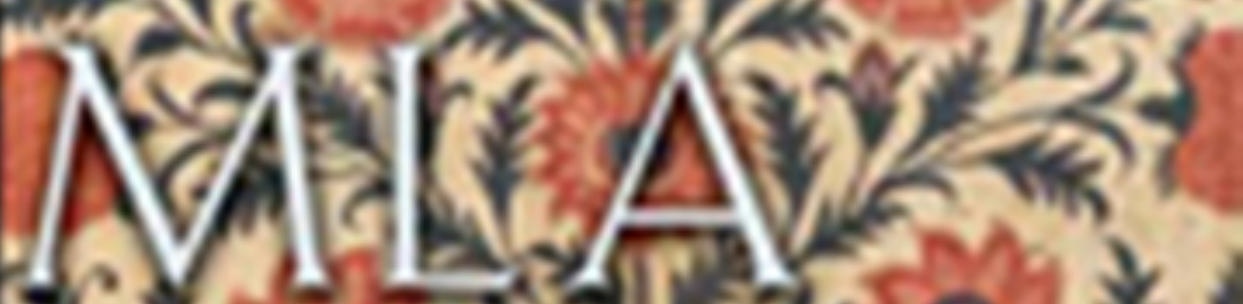

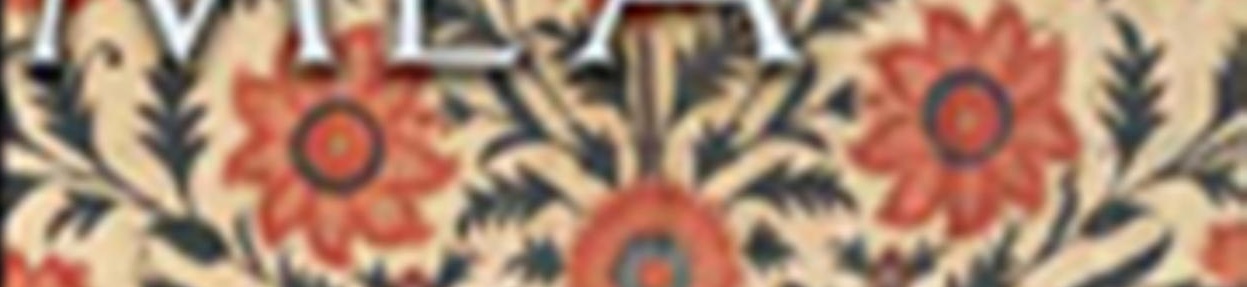

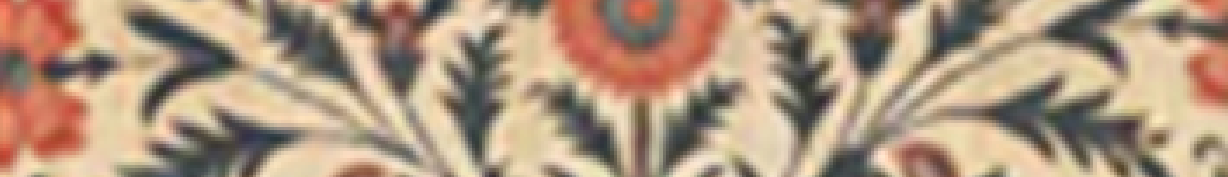

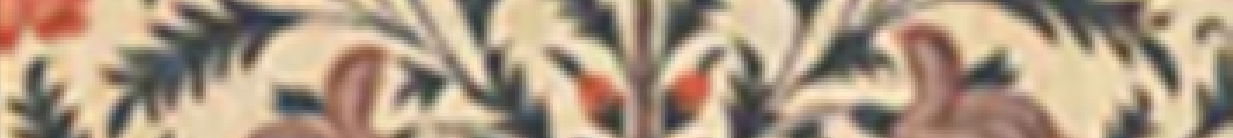

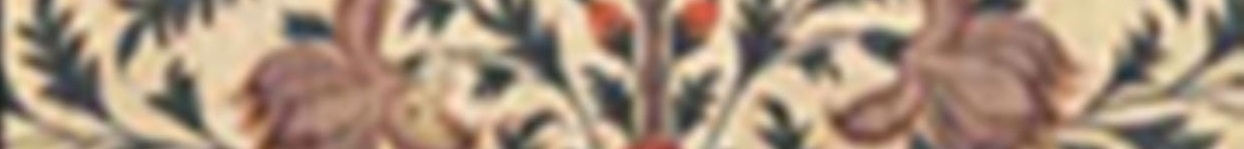

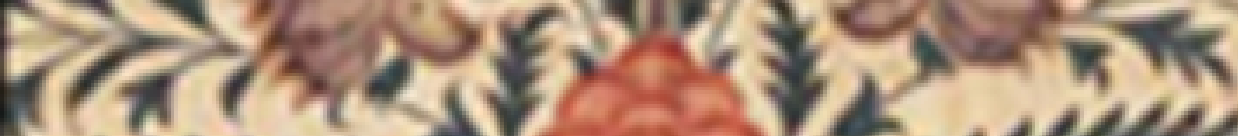

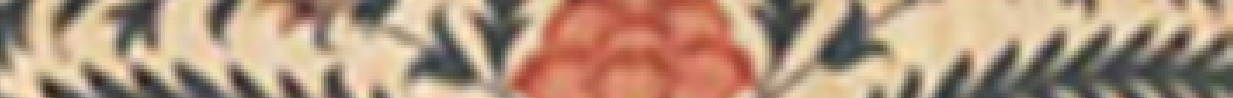
ming,

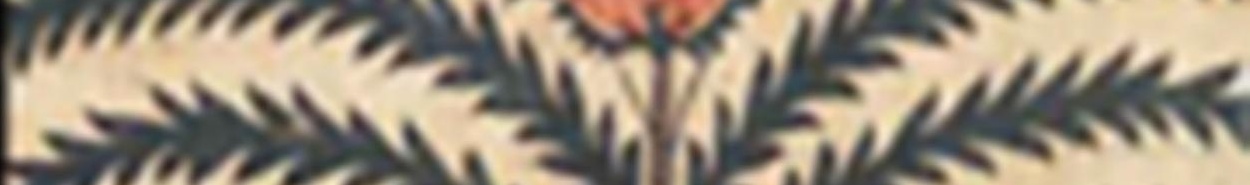

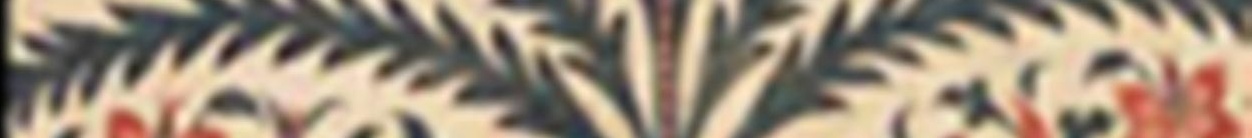

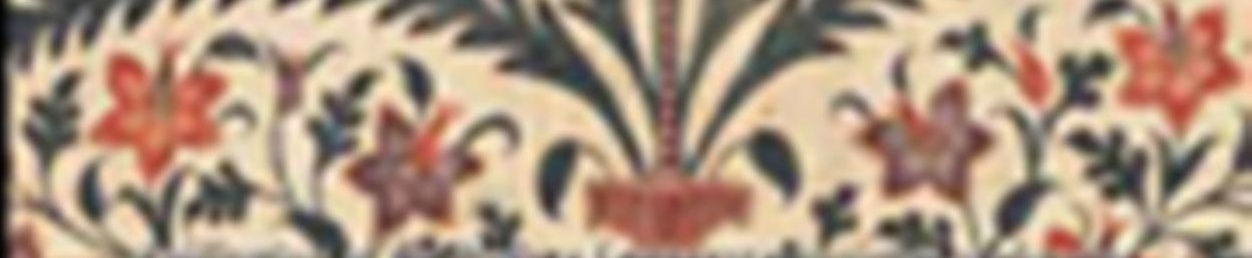

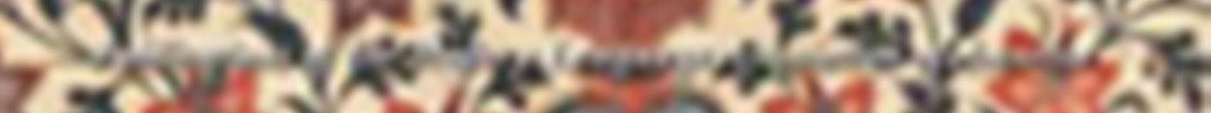
से

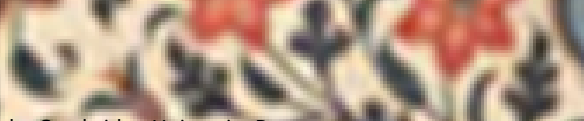




\section{October 2017}

Volume 132 Number 5
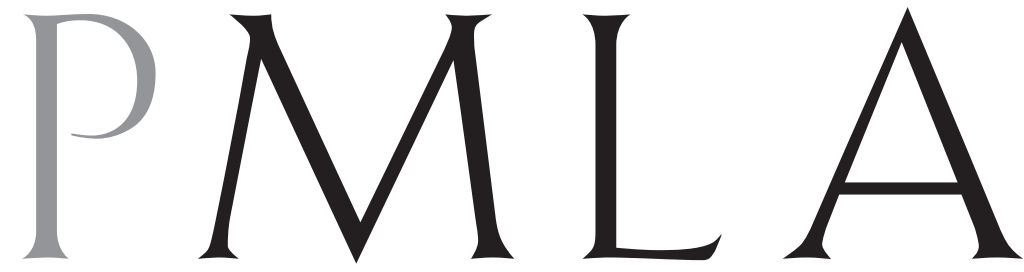

Publications of the Modern Language Association of America 


\section{THE MODERN LANGUAGE} ASSOCIATION OF AMERICA

[ Organized 1883, Incorporated 1900

\section{Officers}

FOR THE TERM ENDING 7 JANUARY 2018

President

Diana TAYlor

New York University

First Vice President

Anne Ruggles Gere

University of Michigan, Ann Arbor

Second Vice President

Simon E. GiKandi

Princeton University

Executive Director

Paula M. Krebs

Executive Council

FOR THE TERM ENDING 7 JANUARY 2018

Brian CROXALL

Brigham Young University, UT

Gaurav G. Desai

University of Michigan, Ann Arbor

Margaret R. Higonnet

University of Connecticut, Storrs

Tracy Denean Sharpley-Whiting Vanderbilt University

FOR THE TERM ENDING 6 JANUARY 2019

\section{EMILY Apter}

New York University

David Palumbo-Liu

Stanford University

VICKY UNRUH

University of Kansas

FOR THE TERM ENDING 12 JANUARY 2020

Angelika Bammer

Emory University

LENORA HANSON

New York University

David Tse-Chien PAN

University of California, Irvine

Rafael A. Ramirez Mendoza

University of California, Los Angeles

FOR THE TERM ENDING 10 JANUARY 2021

Eric Hayot

Penn State University, University Park

Evie SHOCKLEY

Rutgers University, New Brunswick

Dana A. Williams

Howard University

Trustees of Invested Funds

Malcolm B. Smith (Managing Trustee) New York, New York

Domna C. Stanton New York, New York

Catharine R. Stimpson New York, New York

\section{PMLA \\ PUBLICATIONS OF \\ THE MODERN LANGUAGE ASSOCIATION OF AMERICA \\ [ Published five times a year $]$}

Available online at JSTOR and MLAJournals.org;

indexed in the MLA International Bibliography.

Editor

Wai Chee Dimock

Yale University

Managing Editor of MLA Publications

Angela Gibson

Head of Periodical Publications Sara Pastel

Senior Editor

BARNEY LATIMER

Associate Editor

JENNIFER A. RAPPAPORT

\author{
Assistant Editor \\ John D. GolbaCh \\ Advertising Manager and \\ Submissions Associate \\ ANNABel SCHNEIDER \\ Editorial Assistant \\ RAFAEL FONSECA
}

PMLA (ISSN 0030-8129) is published five times a year, in January, March, May, September, and October, by the Modern Language Association of America. Membership in the association is open to persons who are professionally interested in the modern languages and literatures. Information about annual dues, which include subscription to PMLA, is available at www.mla.org/Membership/About-Membership. Membership applications are available on request and at www.mla.org/Membership/Join-the-MLA.

For libraries and other institutions, a subscription in 2017 to the electronic format of PMLA alone is $\$ 210$ and to the print and electronic formats is \$230 (domestic and Canadian) or \$265 (foreign). Subscriptions also include online access to the 2002-16 volumes. Agents deduct four percent as their fee. Claims for undelivered issues will be honored if they are received within six months of the publication date; thereafter the single-issue price will be charged. To order an institutional subscription, call or write MLA Member and Administrative Services (646 576-5166; subscrip@mla.org).

Single copies of issues for the current year and the previous one are available at www .mla.org/store/CID70 and from MLA Member and Administrative Services (646 576-5161; bookorders@mla.org).

The MLA publication and editorial offices are located at 85 Broad Street, suite 500, New York, NY 10004-2434 (646 576-5000; pmlasubmissions@mla.org).

All communications concerning membership, including change-of-address notifications, should be sent to Member and Administrative Services, MLA, 85 Broad Street, suite 500, New York, NY 10004-2434 (646 576-5151; membership@mla.org).

Periodicals postage paid at New York, NY, and at additional mailing offices.

(C) 2017 by The Modern Language Association of America. All rights reserved. Printed in the United States of America. MLA and the MODERN LANGUAGE ASSOCIATION are trademarks owned by the Modern Language Association of America.

Library of Congress Catalog Card Number 12-32040. United States Postal Service Number 449-660.

POSTMASTER: Send address changes to PMLA, Member and Administrative Services, MLA, 85 Broad Street, suite 500, New York, NY 10004-2434. 


\section{Contents}

1085 Submitting Manuscripts to PMLA

1085 Forthcoming in PMLA

1086 Features in PMLA

1089 Editor's Column-Education Populism

1097 Franco's Hajj: Moroccan Pilgrims, Spanish Fascism, and the Unexpected Journeys of Modern Arabic Literature ERIC CALDERWOOD

1117 Oeconomy and Ecology in Early Modern England Peter Remien

1134 Before Infrastructure: The Poetics of Paving in John Gay's Trivia

DAVID AlfF

1149 Remembering the Elephant: Animal Reason before the Eighteenth Century

Bryan AlKemeyer

1166 States of Salvation: Wise Blood and the Rise of the Neoliberal Right

Myka TuCker-Abramson

\section{theories and methodologies}

On Caroline Levine's Forms: Whole, Rhythm, Hierarchy, Network

1181 Whose Forms? Missing Russians in Caroline Levine's Forms

Marijeta Bozovic

1187 Cultural Studies and Close Reading

Angus Connell Brown

1194 Formalism as the Fear of Ideas

Michael W. Clune

1200 Fantastic Forms

LANGDON HAMMER

1206 The Sociology of Forms

Hoyt LONG

1214 The Political Fallacy

SANDRA MacPherson
Editorial Board

Colleen Glenney Boggs, 2018 Dartmouth College

VILASHini CoOppan, 2018

University of California, Santa Cruz

JORGE CORONADO, 2019

Northwestern University

Anjali PrabHu, 2018 Wellesley College

Paul K. Saint-Amour, 2019

University of Pennsylvania

Chenxi TANG, 2019

University of California, Berkeley

Advisory Committee

IDElber V. Avelar, 2019 Tulane University

RALPH BAUER, 2019 University of Maryland, College Park

Karen E. BeCKMAN, 2019

University of Pennsylvania

ANKE BIRKENMAIER, 2020 Indiana University, Bloomington

Heather Blurton, 2018

University of California, Santa Barbara

Edyta M. Bojanowska, 2019

Rutgers University, New Brunswick

CARINe Bourget, 2018

University of Arizona, Tucson

A. Suresh Canagarajah, 2020

Penn State University, University Park

William A. Cohen, 2018

University of Maryland, College Park

BRADIN CORMACK, 2020 Princeton University

Carolyn Dinshaw, 2019 New York University

Daylanne K. English, 2018 Macalester College

REgenia GAGNIER, 2019 University of Exeter

Fred L. Gardaphe, 2019 Queens College, City University of New York

Christina GerhardT, 2019

University of Hawai' $i$, Mānoa

Amalia Gladhart, 2020 University of Oregon

RoBERT J. GRIFFIN, 2019

Texas A\&M University, College Station

Corrinne HAROL, 2018 University of Alberta

HÉctor Hoyos, 2020 Stanford University CAREN IRR, 2020 Brandeis University

JILL M. LANE, 2018 New York University

SEAN LATHAM, 2018 University of Tulsa

(continued) 
Advisory Committee (continued)

NaOmi Iliana Mandel, 2018 University of Rhode Island

MARY MCALPIN, 2020

University of Tennessee, Knoxville

TOM MOLE, 2018

University of Edinburgh

Kate Paesani, 2020

University of Minnesota, Twin Cities

James A. Parente, 2019

University of Minnesota, Twin Cities

JoRge P. PÉREZ, 2020

University of Texas, Austin

Samantha Pinto, 2020

Georgetown University

Ato Quayson, 2018

University of Toronto

JeAn-Michel Rabaté, 2019

University of Pennsylvania

Elizabeth Rhodes, 2020 Boston College

Jill RobBins, 2018

University of California, Merced

Sarah Ruffing Robbins, 2020

Texas Christian University

Debarati Sanyal, 2020

University of California, Berkeley

Elizabeth Sauer, 2018 Brock University

Ken Seigneurie, 2018 Simon Fraser University

Garrett A. Sullivan, 2018 Penn State University, University Park

Anthony Julian TAMburRi, 2019 Queens College, City University of New York

Jane C. Tylus, 2019

New York University

Stefan WheELOCK, 2020

George Mason University

Sharon A. Willis, 2018

University of Rochester

SARAH WINTER, 2020

University of Connecticut, Storrs

JiWEI XIAO, 2018

Fairfield University

Michael G. Ziser, 2019

University of California, Davis
Cover: Tent panel, Burhanpur, India, 172550. Courtesy of the Metropolitan Museum of Art, New York; Friends of Islamic Art Gifts, purchased 2011.
OCTOBER 2017

1220 What Is the New Redistribution?

Anahid Nersessian

1226 Rhythms, Networks: Caroline Levine Meets Susan Howe and Marina Tsvetaeva

STEPHANIE SANDLER

1232 Weird Times

C. NAMwali Ser Pell

1239 Three Unresolved Debates

Caroline Levine

little-known documents

1244 Individual Influence

George Moses Horton

INTRODUCTION BY JONATHAN SENCHYNE

criticism in translation

1251 Seven Remarks on the Seventh Angel

Michel Foucault

InTroduction AND translation by DenNis DUNCAN

1263 Forum

Andrew R. Belton, Doris Sommer, Wai Chee Dimock

1269 Minutes of the MLA Executive Council

1284 In Memoriam

1286 Index of Advertisers

1295 Abstracts 